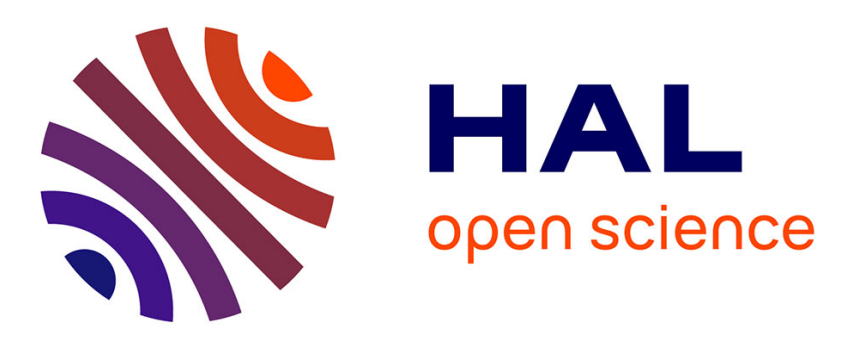

\title{
Ageing of polyvinylidene fluoride hollow fiber membranes in sodium hypochlorite solutions
}

J Ravereau, A Fabre, A Brehant, A Bonnard, C Sollogoub, J Verdu

\section{To cite this version:}

J Ravereau, A Fabre, A Brehant, A Bonnard, C Sollogoub, et al.. Ageing of polyvinylidene fluoride hollow fiber membranes in sodium hypochlorite solutions. Journal of Membrane Science, 2016, 505, pp.174-184. 10.1016/j.memsci.2015.12.063 . hal-01300658

\section{HAL Id: hal-01300658 \\ https://hal.science/hal-01300658}

Submitted on 11 Apr 2016

HAL is a multi-disciplinary open access archive for the deposit and dissemination of scientific research documents, whether they are published or not. The documents may come from teaching and research institutions in France or abroad, or from public or private research centers.
L'archive ouverte pluridisciplinaire HAL, est destinée au dépôt et à la diffusion de documents scientifiques de niveau recherche, publiés ou non, émanant des établissements d'enseignement et de recherche français ou étrangers, des laboratoires publics ou privés. 


\title{
Ageing of polyvinylidene fluoride hollow fiber membranes in sodium hypochlorite solutions
}

\author{
J. Ravereau ${ }^{\mathrm{a}, \mathrm{b}}$, A. Fabre ${ }^{\mathrm{a}}$, A. Brehant ${ }^{\mathrm{a}}$, R. Bonnard ${ }^{\mathrm{a}}$, C. Sollogoub ${ }^{\mathrm{b}, *}$, J. Verdu $^{\mathrm{b}}$ \\ a CIRSEE, SUEZ Environnement, 38 rue du Président Wilson, 78230 Le Pecq, France \\ b PIMM, UMR 8006, Arts et Métiers ParisTech, CNRS, CNAM, 151 boulevard de l'Hôpital, 75013 Paris, France
}

\begin{abstract}
A B S T R A C T
In order to study the effect of cleaning operations on polyvinylidene fluoride (PVDF) hollow fiber membrane stability, ageing of two PVDF based membranes (one is additive free, the other contains hydrophilic additives) in contact with sodium hypochlorite solutions with various $\mathrm{pH}$ values has been studied. The aim of this experimental study was to identify the degradation mechanisms and to gain a better understanding of the effect of the (macro)molecular structure changes on the mechanical and functional properties of the membranes. In both membranes, double bond formation, chain scission and crosslinking are observed and all these processes (except crosslinking) are faster in acidified solutions than in natural $\mathrm{NaOCl}$ solutions ( $\mathrm{pH}$ 11.5). It can be deduced that if ionic processes such as dehydrofluorination occur, radical processes resulting from the presence of hypochlorous acid and perhaps its coexistence with the $\mathrm{ClO}^{-}$ion, predominate in acidified solutions. The presence of non-fluorinated aliphatic or cycloaliphatic additives, which are highly reactive with bleach, accelerates chain scission at the expense of crosslinking. In the chosen conditions ( 135 days in $4000 \mathrm{ppm}$ bleach solutions at $40{ }^{\circ} \mathrm{C}$ ), PVDF chains are degraded but not enough to induce polymer embrittlement. While in the additive free membrane no significant change of the use properties has been observed, the polymeric additives of the other membrane are completely destroyed, leading to a decrease of the membrane hydrophilicity, but their destruction improves the membrane selectivity by a decrease of the average porosity.
\end{abstract}

\section{Introduction}

There is currently a growing interest in using polymeric hollow fiber membranes in the industry of wastewater treatment, for micro-filtration (typically for bacteria retention) and ultra-filtration (typically for virus retention) [1,2]. Many engineering polymers are used as membrane material, such as cellulose acetate, polyacrylonitrile, polytetrafluorethylene, aromatic polysulfones [3]. More recently, polyvinylidene fluoride [4-7] has gained considerable attention as a membrane material due to its outstanding properties: high mechanical strength, flexibility, thermal stability, chemical resistance and good processability.

One of the major problems associated with membrane filtration processes is the problem of fouling that is susceptible to modify the membrane properties like permeate flux, hydrophobicity, pore size distribution, possibly altering its filtration ability $[8,9]$. In order to restore the membrane properties, chemical cleaning is routinely performed using different corrosive chemical

\footnotetext{
* Corresponding author.

E-mail address: cyrille.sollogoub@cnam.fr (C. Sollogoub).
}

agents, among which sodium hypochlorite remains popular, due to its low price and efficiency $[10,11]$.

The impact of sodium hypochlorite solutions on properties of membranes has been reported by several authors and different effects, often correlated, have been highlighted. For instance, some studies have observed a partial chain scission of membrane polymer provoked by the interactions between the sodium hypochlorite and the membrane polymer: polysulfone [12,13], polyethersulfone [14] and cellulose acetate [15]. In parallel, degradation and/or removal of the additives, often present in the membrane polymers, may result in some properties modifications. Thus, Wienk et al. [16] have reported PVP consumption in a PES/ PVP membrane when cleaned by exposure to sodium hypochlorite solutions, leading to a drastic change of the water permeability of the membrane. Similar results have been found by Quin et al. for PSU/PVP [17] and CA/PVP [18] membranes. Pellegrin et al. [19] have shown that the degradation of PVP in a PES/PVP membrane is responsible for a superficial oxidation of the membrane. Changes in membrane surface chemistry leading to a gradual deterioration of membrane integrity have been evidenced by other authors, like Gitis et al. [15] after cleaning of a cellulose triacetate membrane 
with bleach solution.

Even if PVDF is commonly considered as a polymer highly resistant, it is known to be vulnerable to strong base solutions, through the mechanism of dehydrofluorination inducing hydrogen fluoride elimination and double bond formation [20,21]. The stability of PVDF membranes in sodium hydroxide has been investigated [22-24] and a loss of mechanical integrity has been highlighted under harsh treatment conditions. Concerning the effect of sodium hypochlorite solution on PVDF membrane, limited literature is available (Hajibabania et al. [25], Puspitasari et al. [26], Wang et al. [6], Arkhangelsky et al. [27] and Rabuni et al. [28]). The authors have mainly focused on the effect of fouling and cleaning with sodium hypochlorite solutions on the membrane performance, and they have evidenced some modifications of the functional and mechanical properties of the membranes. A 35\% decrease of nominal elongation has been measured by Rabuni et al. [28] for an additivated PVDF membrane under exposure to $0.1 \mathrm{M}$ $\mathrm{NaOCl}$ solution at $50{ }^{\circ} \mathrm{C}$ during $60 \mathrm{~min}$. A deterioration of mechanical properties of the membrane had also been reported by previous works $[6,25]$. The modification of the membrane hydrophobicity has been explained $[25,28,29]$ either by degradation and consumption of hydrophilic additives or by oxidation of the surface for additive free PVDF membrane. However, a systematic study on the effect of the different reactive species present in sodium hypochlorite solutions on PVDF membrane stability is still lacking.

In this study the effect of sodium hypochlorite solutions on two PVDF filtration membranes has been investigated: one is additive free and the other is modified by hydrophilic additives. Since the chemistry of sodium hypochlorite solutions is $\mathrm{pH}$ dependent and in order to gain better understanding of the degradation mechanism, the $\mathrm{pH}$ value of the solution has been varied, modifying the concentration of ionic and radical reactive species. With the aim of establishing a link with the mechanical and functional membrane properties, the changes in the molecular and macromolecular structures of the membranes have been monitored.

\section{Experimental}

\subsection{Materials}

Two distinct commercially available hollow-fiber membranes were studied: one destined for microfiltration, named PVDF (0) and another destined for ultrafiltration, named PVDF(AH). Certain details of their structure can be seen on the SEM micrographs in Fig. 1.

Their outer diameter is about $1.3 \mathrm{~mm}$, the (porous) walls having about $0.3 \mathrm{~mm}$ thickness. Some characteristics of the two membranes, obtained from different physico-chemical analysis, are listed in Table 1.

These characteristics call for the following comments: the main difference is the presence in $\operatorname{PVDF}(\mathrm{AH})$ and the absence in PVDF (0) of hydrophilic polymers such as polyvinylpyrrolidone (PVP) and polyethylene glycol (PEG). PVP is classically incorporated to the material in order to improve its hydrophilicity (Table 1 ). PEG is rather a processing additive which has not been totally eliminated at the end of the membrane elaboration process. No doubt, PEG contributes also to the increase of hydrophilicity.

Number average $M_{\mathrm{n}}$ and weight average $M_{\mathrm{w}}$ molar masses have

\begin{tabular}{|c|c|c|c|}
\hline Sample & Outer skin & Inner skin & Cross-section \\
\hline \multicolumn{4}{|l|}{ PVDF(0) } \\
\hline \multicolumn{4}{|c|}{ Observation zones } \\
\hline \multicolumn{4}{|l|}{ PVDF(0) } \\
\hline \multicolumn{4}{|l|}{$\operatorname{PVDF}(\mathrm{AH})$} \\
\hline \multicolumn{4}{|c|}{ Observation zones } \\
\hline PVDF(AH) & & & \\
\hline
\end{tabular}

Fig. 1. SEM images of the PVDF hollow fiber membranes. 
Table 1

Physico-chemical characteristics of the membranes.

\begin{tabular}{|c|c|c|c|c|c|c|c|c|c|}
\hline Characteristic & $\begin{array}{l}\text { PVP }^{\mathrm{a}} \\
(\%)\end{array}$ & $\begin{array}{l}\text { PEG }^{\mathrm{b}} \\
(\%)\end{array}$ & $\begin{array}{l}M_{\mathrm{n}} \\
\left(\mathrm{kg} \mathrm{mol}^{-1}\right)\end{array}$ & $\begin{array}{l}M_{\mathrm{w}} \\
\left(\mathrm{kg} \mathrm{mol}^{-1}\right)\end{array}$ & PDI & $\begin{array}{l}T_{\mathbf{m}} \\
\left({ }^{\circ} \mathbf{C}\right)\end{array}$ & $\begin{array}{l}\chi_{c}{ }^{c} \\
(\%)\end{array}$ & $F_{\beta}{ }^{d}$ & $\begin{array}{l}\boldsymbol{T}_{\mathbf{g}}{ }^{\mathrm{e}} \\
\left({ }^{\circ} \mathbf{C}\right)\end{array}$ \\
\hline PVDF(0) & 0 & 0 & 102 & 262 & 2.56 & 177 & 53 & $0.4-0.5$ & -42 \\
\hline PVDF(AH) & 2.9 & 6.5 & 213 & 897 & 4.21 & 165 & 46 & 0.8 & -54 \\
\hline
\end{tabular}

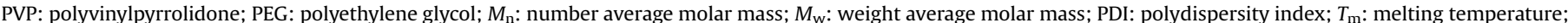
$X_{\mathrm{c}}$ : degree of crystallinity; $F_{\beta}$ : relative fraction of the $\beta$ phase; $T_{\mathrm{g}}$ : glass transition temperature.

${ }^{a}$ Calculated from the nitrogen mass fraction determined by elemental analysis.

b Calculated from integration of the peak at $3.54 \mathrm{ppm}$ in proton NMR spectrum. NB: PVP is expected to appear at 1.88 ppm but its peak is too weak to be measured, which explains the use of elemental analysis for its determination.

${ }^{\mathrm{c}}$ Calculated from the area of the melting endotherm (DSC) without correction for the presence of additives.

${ }^{\mathrm{d}}$ Calculated from the relationship [30]: $F_{\beta}=I_{\beta} /\left(1.3 I_{\alpha}+I_{\beta}\right)$ where $I_{\alpha}$ and $I_{\beta}$ are the respective absorbance of the IR peaks at $763 \mathrm{~cm}^{-1}(\mathrm{phase} \alpha)$ and $841 \mathrm{~cm}^{-1}(\mathrm{phase} \beta$ ).

e Determined by DSC.

been determined from steric exclusion chromatograms (see below). The chromatogram of $\operatorname{PVDF}(\mathrm{AH})$ results from the superposition of the PVDF matrix one and those of polymeric additives PVP and PEG, however these latter are in relatively low concentration and the difference in molar masses of $\operatorname{PVDF}(0)$ and $\operatorname{PVDF}(\mathrm{AH})$ is mainly linked to a difference in PVDF matrices.

Both membranes differ also by their melting characteristics: the melting point and the glass transition temperature of PVDF $(\mathrm{AH})$ are about $12^{\circ} \mathrm{C}$ below the $\operatorname{PVDF}(0)$ ones that clearly indicates a plasticizing effect of a polymeric additive, presumably PEG. The existence of such plasticizing effect is only possible if the additives are at least partially miscible to PVDF.

Finally, both PVDF matrices differ also by their crystalline structure since the content of $\beta$ phase is almost twice in $\operatorname{PVDF}(\mathrm{AH})$ than in $\operatorname{PVDF}(0)$. This difference indicates that both membranes have a distinct thermo-mechanical story as confirmed in Fig. 1, where crazes can be observed only in the inner skin of PVDF(AH). These crazes, which have been presumably voluntarily created to generate a controlled porosity, indicate the existence of highly orientated (fibrilar) regions probably responsible for the observed differences in crystalline structure.

\subsection{Physico-chemical analysis}

Infrared spectra were recorded in ATR mode with a Shimadzu IR Affinity 1 apparatus. 40 scans were averaged for a resolution of $8 \mathrm{~cm}^{-1}$

NMR spectra were recorded with a Bruker Advance III HD 400 spectrometer. The samples were dissolved in deuterated dimethyl sulfoxide at $60^{\circ} \mathrm{C}$. Various probes were used but only results obtained on proton spectra will be reported here.

Steric exclusion chromatograms (SEC) of $2 \mathrm{~g} \mathrm{~L}^{-1}$ prefiltered sample solutions in dimethyl acetamide were recorded with a WATERS apparatus equipped with four GRAM PSS $10 \mu \mathrm{m}$ columns of $7.5 \times 300 \mathrm{~mm}^{2}$ : one pre-column, two $10,000 \mathrm{~A}$ columns and one $100 \mathrm{~A}$ column. The detector was a differential refractometer WATERS 2414. Calibration was performed with quasi homodisperse polystyrene fractions of molar mass ranging from 0.47 to $6040 \mathrm{~kg} \mathrm{~mol}^{-1}$.

Differential scanning calorimetry (DSC) measurements were made on a Netzsch DSC 200 P3 Maia apparatus on samples of 5$10 \mathrm{mg}$, between $-100^{\circ} \mathrm{C}$ and $250^{\circ} \mathrm{C}$ with a temperature ramp of $20{ }^{\circ} \mathrm{C} \mathrm{min}^{-1}$.

\subsection{Porosity and transport properties}

Water absorption. The water absorption capacity of membranes was determined at $50{ }^{\circ} \mathrm{C}$ in the $0-90 \%$ relative humidity (RH) range, using a gravimetric system (DVS 1000 from Surface Measurement Systems - London). The relative humidity is increased by increments of $10 \%$ and the mass gain is recorded until equilibrium is reached. Sorption isotherms will be presented in the "Results" section.

Nitrogen absorption. Measurements of nitrogen absorption have been made at $77 \mathrm{~K}$ using a Belcorp-mini $\mathrm{H}$ apparatus from Bel Japan Inc. The sorption isotherms can be used to determine the global porosity (volume fraction of the pores) and the specific area.

Hydraulic permeability. Membrane permeability to liquid water was determined on mini-modules of 23 hollow fibers, using a dedicated MEMlab ${ }^{\circledR}$ platform. For a given pressure difference $\Delta P$ (bar) between both faces of the membrane and a filtrating surface $S\left(\mathrm{~m}^{2}\right)$, the flow is $Q\left(\mathrm{~L} \mathrm{~h}^{-1}\right)$ and the water permeability $L_{\mathrm{P}}$ $\left(\mathrm{L} \mathrm{m}^{-2} \mathrm{~h}^{-1} \mathrm{bar}^{-1}\right)$ is defined by:

$L_{P}=\frac{Q}{S \Delta P}$

Virus and bacteria retention. Measurements have been made using the MEMlab ${ }^{\circledR}$ platform, on MS2 virus and on Escherichia Coli bacteria. If $C 1$ and $C 2$ are the concentrations of the migrating species respectively in the starting solution and in the filtrated solution, the retention ratio LRV is defined by:

$\mathrm{LRV}=\log \frac{C 1}{\mathrm{C} 2}$

The main porosity and transport characteristics of unaged membranes are reported in Table 2.

\subsection{Ageing tests}

Ageing tests have been realized at $40{ }^{\circ} \mathrm{C}$ in $4000 \mathrm{ppm}$ sodium hypochlorite $(\mathrm{NaOCl})$ solutions, at three distinct $\mathrm{pH}$ values: 6.0, 7.5 and 11.5. This latter value is the $\mathrm{pH}$ of a "pure" $\mathrm{NaOCl}$ solution. To obtain lower $\mathrm{pH}$ values, $\mathrm{HCl}\left(1 \mathrm{~mol} \mathrm{~L}^{-1}\right)$ was added. As it will be seen, ageing of additive free PVDF is extremely slow in such medias, unfortunately it appeared difficult to work in more severe conditions i.e. at higher temperatures or in more concentrated

Table 2

Some use properties of the membranes.

\begin{tabular}{|c|c|c|c|c|c|c|}
\hline Property & $\begin{array}{l}\text { LRV } \\
\text { virus MS2/E. coli }\end{array}$ & $\begin{array}{l}\text { Water permeability } \\
\left(\mathrm{L} \mathrm{h}^{-1} \mathrm{~m}^{-2} \text { bar }^{-1}\right)\end{array}$ & $\begin{array}{l}\text { Water absorption } \\
\left(\% \text { at } 90 \% \mathrm{RH}, 50{ }^{\circ} \mathrm{C}\right)\end{array}$ & $\begin{array}{l}\text { Porosity } \\
\text { (\%) }\end{array}$ & $\begin{array}{l}\text { Average pore size } \\
(\mathbf{n m})\end{array}$ & $\begin{array}{l}\text { Specific area } \\
\left(\mathrm{m}^{2} \mathrm{~g}^{-1}\right)\end{array}$ \\
\hline PVDF(0) & $0.07 / 7.73$ & $2013 \pm 54$ & 0.09 & $73.9 \pm 0.3$ & 100 & $10 \pm 2$ \\
\hline PVDF(AH) & $1.19 />10$ & $539 \pm 78$ & 2.9 & $78.4 \pm 0.3$ & 30 & $18 \pm 3$ \\
\hline
\end{tabular}


solutions because they are unstable at the point that, even for $4000 \mathrm{ppm}$ solutions it was necessary to renew the bath 3 times per week (for a total ageing duration of about 5 months).

The mechanisms of $\mathrm{NaOCl}$ action in water have been investigated by several authors [16]. It has been shown that $\mathrm{NaOCl}$ decomposes into various ions $\left(\mathrm{Cl}^{-}, \mathrm{ClO}^{-}, \mathrm{Na}^{+}\right.$, etc.) and free radicals $\left(\mathrm{HO}^{\bullet}, \mathrm{ClO}^{\bullet}, \mathrm{Cl}^{\bullet}\right.$, etc.). The nature of predominant reactive species depends on the $\mathrm{pH}$ value. It is generally recognized that ions are insoluble in polymers of low polarity such as PVDF and inactive in ageing processes as demonstrated by their remarkable stability in highly acidic or basic media. In contrast, free radicals, which are less polar than ions, can penetrate in polymers and induce ageing processes. Among the above cited radicals, hydroxyl $\left(\mathrm{HO}^{\bullet}\right)$ ones are especially reactive and their small size allows their fast diffusion into polymer matrices; this is the reason why they have been considered by many authors as the species responsible for polymer ageing in $\mathrm{NaOCl}$ solutions [16,19,27,31]. Ageing tests have been performed at $40{ }^{\circ} \mathrm{C}$ in sodium hypochlorite solutions at a total free chlorine concentration of $0.054 \mathrm{~mol} \mathrm{~L}^{-1}$.

\section{Results}

\subsection{Spectrochemical data}

Infrared spectra are shown in Fig. 2a for $\operatorname{PVDF}(0)$ and Fig. 2b for $\operatorname{PVDF}(\mathrm{AH})$. The modifications are almost imperceptible in the chosen absorbance scale. A zoom in the $1400-2000 \mathrm{~cm}^{-1}$ interval (Fig. 3a (PVDF(0)) and Fig. 3b (PVDF(AH))), reveals however minute modifications in the carbonyl and in the double bond regions.

In the case of $\operatorname{PVDF}(0)$, one observes the growth of a band at $1650 \mathrm{~cm}^{-1}$ for samples exposed at $\mathrm{pH} 6.0$ or 7.5 , but not at $\mathrm{pH} 11.5$. In the case under study, this band can be attributed to double bonds, there is no alternative for its assignment. In particular, oxidation products such as hydroxyl or carbonyl groups are undetectable.

In the case of $\operatorname{PVDF}(\mathrm{AH})$, a carbonyl peak preexists at $1662 \mathrm{~cm}^{-1}$ in unaged samples. It corresponds to the amide group of PVP. This peak disappears rapidly during ageing while a new peak appears at $1650 \mathrm{~cm}^{-1}$ for the samples exposed at $\mathrm{pH} 6.0$ or 7.5, as for $\operatorname{PVDF}(0)$.

$N M R{ }^{13} \mathrm{C}$ spectra are shown in Fig. 4 for PVDF(0). NMR spectra of $\operatorname{PVDF}(\mathrm{AH})$ samples are similar and will not be presented here.

Additives are not detectable in ${ }^{13} \mathrm{C}$ spectra, in contrast certain irregular structures, such as head to head (ethylene) bonds and double bonds (confirming IR observations) can be observed. The corresponding integrations led to Table 3.

These data call for the following comments. In the case of PVDF (0) one observes the disappearance of ethylene groups and the

A

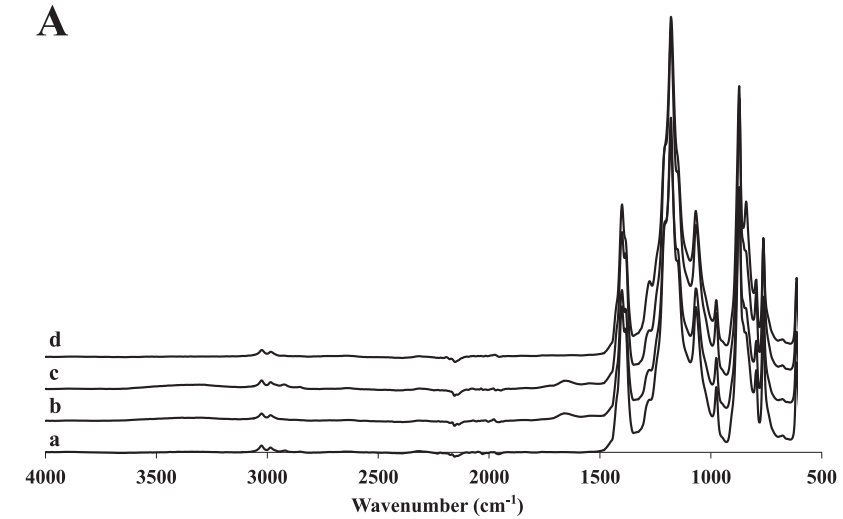

formation of double bonds. It is not unreasonable to assume that double bonds have been formed at the expense of ethylene groups. The situation is more complicated in the case of PVDF(AH). Double bonds are also formed in almost same quantities as in $\operatorname{PVDF}(0)$, which is not surprising since initial ethylene concentrations are very close. The fact that for both membranes, from the point of view of double bond formation, the reactivity is in the order of $\mathrm{pH}$ : $6.0>7.5 \gg 11.5$ and that in a given medium both rates are almost equal, does not result from a coincidence; it is due to the fact that double bonds result from direct attack of PVDF macromolecules by reactive species almost exclusively present in solutions of $\mathrm{pH}<11.5$, the reaction being unaffected by the presence or not of additives such as PVP or PEG.

In the case of PVDF(AH), NMR, in the chosen conditions, does not bring direct information. However one can observe in Table 4 that the ethylene concentration seems to increase significantly after ageing that is, indeed, unlikely. It can be supposed that this effect results from the additive presence at the beginning of exposure but the mechanism remains unknown.

It can be remarked that the ethylene concentration decreases significantly (in $\operatorname{PVDF}(0)$ ) while the concentration of head to tail bonds remains almost constant despite the fact that it is about 12 times higher than ethylene one. One can conclude that, in the conditions under study, PVDF head to tail sequences are almost totally unreactive, hypochlorite solutions attack the polymer only at "weak points" such as ethylene groups but this attack remains limited. In contrast polymeric additives such as PVP or PEG are rapidly transformed into undetectable oxidation products.

The fact that the solution of $\mathrm{pH} 11.5$ is considerably less reactive than the other ones can be understood on the basis of available analytical studies showing that molecular $(\mathrm{ClOH})$ (and presumably radical) species are highly favored at $\mathrm{pH} 6.0$, less at $\mathrm{pH} 7.5$ and inexistent at $\mathrm{pH}>9.0$ where all the present species are ionic.

\subsection{Molar mass distribution data}

Examples of SEC chromatograms of samples exposed 135 days in solutions at pH 6.0 and 7.5 are shown in Fig. 5.

The number and weight molar mass averages are given in Table 4 . The first remark which comes in mind is that the whole distribution is affected but remains unimodal. This is only possible if the totality of the sample volume has reacted. In the case of localized chemical reaction, the distribution is expected to become bimodal. Indeed we do not exclude the hypothesis of coexistence of the observed global reaction with a strongly localized one, of which the volume fraction would be too small to be detected by SEC. Supposing a priori that the global chain scission and crosslinking processes responsible for molar mass changes occur on randomly distributed sites and that the reaction is homogeneous,

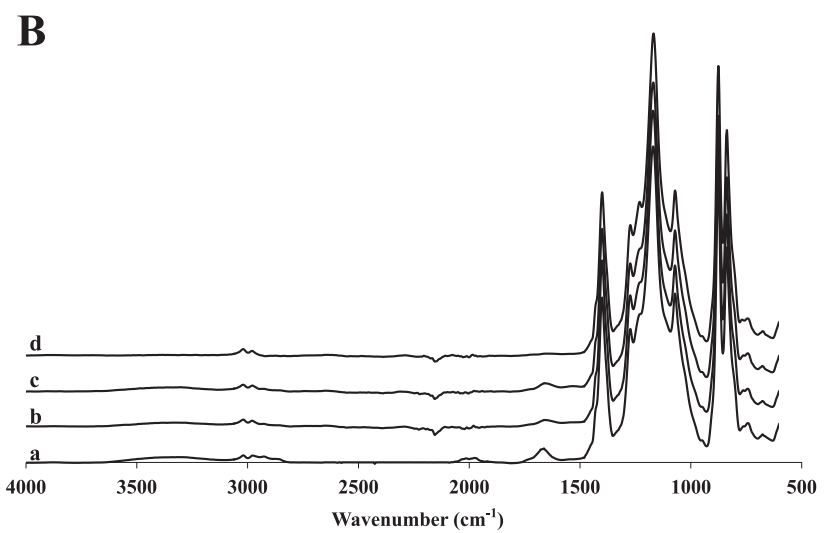

Fig. 2. Infrared spectra before (a) and after 135 days ageing in $\mathrm{NaOCl} 4000 \mathrm{ppm}$ at $40{ }^{\circ} \mathrm{C}$ for $\mathrm{pH}=6.0$ (b), 7.5 (c) and 11.5 (d) left $\mathrm{PVDF}(0)$, right $\mathrm{PVDF}(\mathrm{AH})$. 

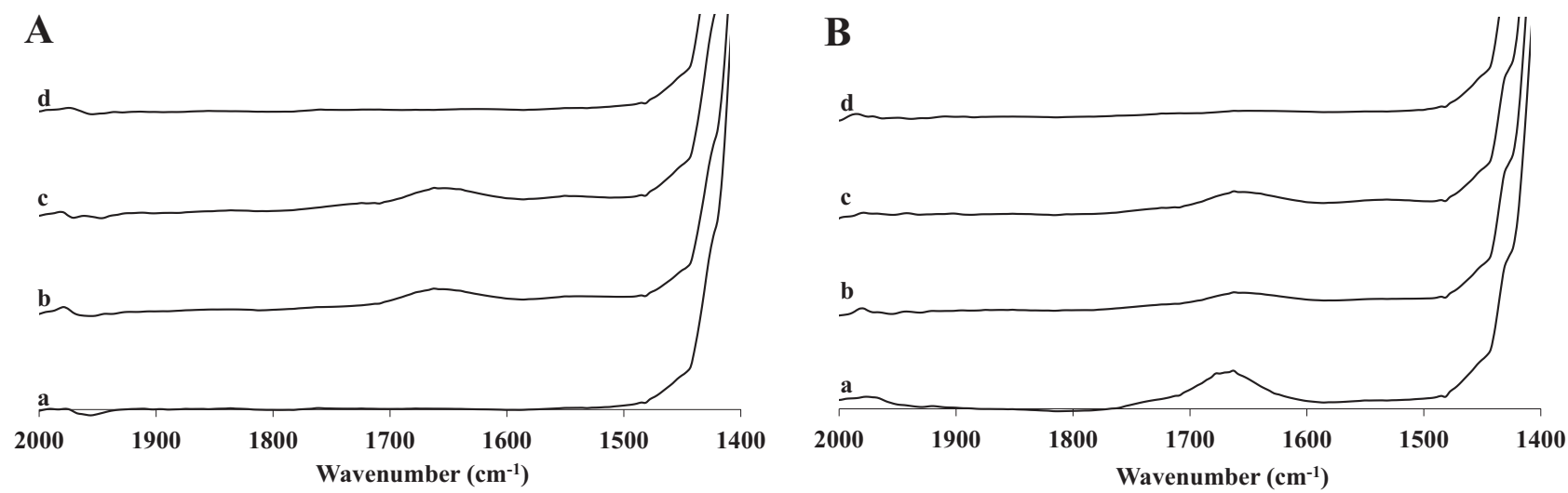

Fig. 3. Zoom on the $1400-2000 \mathrm{~cm}^{-1}$ interval for the spectra of Fig. 2. A: PVDF(0), and B: PVDF(AH).

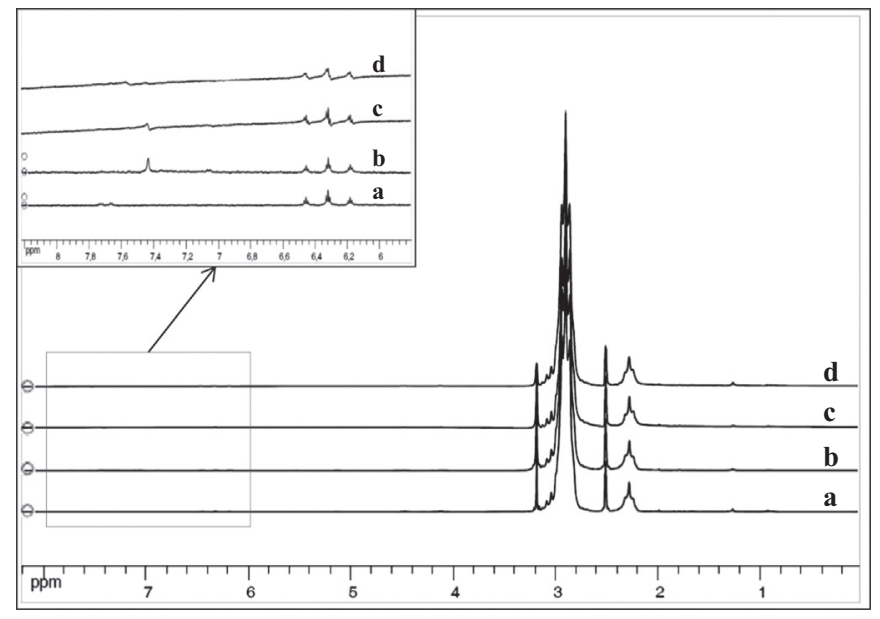

Fig. 4. $\mathrm{NMR}{ }^{13} \mathrm{C}$ spectra. From top to bottom: initial, $\mathrm{pH}=6.0, \mathrm{pH}=7.5$, and $\mathrm{pH}=11.5$.

Table 3

Molar fractions (\%) of the main skeleton bonds from integration of ${ }^{13} \mathrm{CNMR}$ spectra.

\begin{tabular}{|c|c|c|c|c|}
\hline Sample & $\begin{array}{l}\text { Ageing } \\
\text { conditions }\end{array}$ & $\begin{array}{l}\sim\left(\mathrm{CF}_{2}-\mathrm{CH}_{2}\right) \sim \\
2.88 \mathrm{ppm}\end{array}$ & $\begin{array}{l}\sim\left(\mathrm{CF}_{2}-\mathrm{CH}_{2}-\mathrm{CH}_{2}-\mathrm{CF}_{2}\right) \\
\sim 2.27 \mathrm{ppm}\end{array}$ & $\begin{array}{l}\sim \mathrm{C}=\mathrm{C} \sim \\
7.44 \mathrm{ppm}\end{array}$ \\
\hline PVDF & Initial & 92.70 & 7.30 & - \\
\hline \multirow[t]{3}{*}{ (0) } & $\begin{array}{l}\text { NaOCl pH } \\
\text { 6-135 days }\end{array}$ & 92.81 & 7.16 & 0.03 \\
\hline & $\begin{array}{l}\mathrm{NaOCl} \text { pH } \\
7.5-135 \text { days }\end{array}$ & 93.17 & 6.81 & 0.02 \\
\hline & $\begin{array}{l}\text { NaOCl pH 11.5- } \\
135 \text { days }\end{array}$ & 92.93 & 7.07 & - \\
\hline \multirow{4}{*}{$\begin{array}{l}\text { PVDF } \\
\text { (AH) }\end{array}$} & Initial & 92.30 & 7.70 & - \\
\hline & $\begin{array}{l}\text { NaOCl pH } \\
6-135 \text { days }\end{array}$ & 91.26 & 8.70 & 0.04 \\
\hline & $\begin{array}{l}\mathrm{NaOCl} \text { pH } \\
7.5-135 \text { days }\end{array}$ & 91.51 & 8.46 & 0.03 \\
\hline & $\begin{array}{l}\mathrm{NaOCl} \text { pH } \\
11.5-135 \text { days }\end{array}$ & 91.13 & 8.87 & - \\
\hline
\end{tabular}

one can use Saito's equations [32] to determine the numbers of chain scissions $s$ and crosslinks $x$ per mass unit:

$\frac{1}{M_{\mathrm{n}}}-\frac{1}{M_{\mathrm{n} 0}}=\delta_{\mathrm{s}}=s-x$
$\frac{1}{M_{\mathrm{w}}}-\frac{1}{M_{\mathrm{w} 0}}=\delta_{\mathrm{w}}=\frac{s}{2}-2 x$

where $\delta_{\mathrm{s}}$ and $\delta_{\mathrm{w}}$ are the respective changes in reciprocal number and weight average molar masses.

From this system of equations on obtains:

$s=\frac{2}{3}\left(2 \delta_{\mathrm{s}}-\delta_{\mathrm{w}}\right)$

$x=\frac{1}{3}\left(\delta_{\mathrm{s}}-2 \delta_{\mathrm{w}}\right)$

All the above quantities are listed in Table 4 . These results call for the following comments: Molar mass changes after 60 days are generally small therefore errors on $s$ and $x$ are very important so that we will limit the discussion to the results obtained after 135 days. Let us first focus on the exposures at pH 6.0 and 7.5.

For both membranes exposed 135 days, $s$ and $x$ are positive, which means that they have eventually a physical meaning in the frame of the chosen set of hypotheses (random character, homogeneous reaction).

It can be remarked that in all the cases $s>4 x$. In other words scission predominates over crosslinking. But it can be also remarked that $s / 4 x \sim 4-5$ for $\operatorname{PVDF}(0)$ and 33-35 for $\operatorname{PVDF}(\mathrm{AH})$; in other words, $\operatorname{PVDF}(0)$ is close to the equilibrium between scission and crosslinking (for $s / x>4$, the sample must undergo gelation, whereas for $s / x<4$, it undergoes continuous degradation). In contrast, for $\mathrm{PVDF}(\mathrm{AH})$, degradation largely predominates over crosslinking.

It can be recalled that in the case of random chain scission and negligible crosslinking, the polydispersity index (PDI) is expected to tend towards 2.0 whatever its initial value, the rate of PDI change being all the more faster as its initial value is far from 2.0. Here, it can be observed that, for $\operatorname{PVDF}(0)$, the PDI value (initially 2.57) undergoes only small changes in acidified solutions because the effect of chain scission is counterbalanced by the effect of crosslinking that contributes to widen the chain length distribution. In the case of PVDF(AH), in contrast, crosslinking is negligible, the initial PDI value (4.21) is higher than for $\operatorname{PVDF}(0)$ and degradation induces a very significant decrease of PDI.

In the case of exposures in solutions at $\mathrm{pH} 11.5$, the behavior of $\operatorname{PVDF}(0)$ is totally different; $s$ and $x$ are negative, indicating the non-validity of starting hypotheses. Since the distribution remains unimodal, there is no reason to reject the hypothesis of reaction homogeneity; thus we are leaded to examine the hypothesis relative to the random distribution of reactive sites along the chains. In principle, an increase of average molar masses is interpreted in terms of crosslinking but in this case, the absolute value of $\delta_{\mathrm{w}}$ is 
Table 4

Average molar masses, number of chain scissions and crosslinks per mass unit

\begin{tabular}{|c|c|c|c|c|c|c|c|c|}
\hline Sample & $\begin{array}{l}\text { Ageing } \\
\text { Conditions }\end{array}$ & $\begin{array}{l}\text { Exposure duration (days) } \\
\left(\mathrm{kg} \mathrm{mol}^{-1}\right)\end{array}$ & $\boldsymbol{M}_{\mathbf{n}}\left(\mathrm{kg} \mathrm{mol}^{-1}\right)$ & $\boldsymbol{M}_{\mathbf{w}}\left(\mathrm{kg} \mathrm{mol}^{-1}\right)$ & $\delta_{\mathbf{n}}\left(\mathrm{mol}^{-1} \mathrm{~kg}\right)$ & $\delta_{\mathbf{w}}\left(\mathrm{mol}^{-1} \mathrm{~kg}\right)$ & $\boldsymbol{s}\left(\mathrm{mol}^{-1} \mathrm{~kg}\right)$ & $\boldsymbol{x}\left(\mathrm{mol}^{-1} \mathrm{~kg}\right)$ \\
\hline \multirow[t]{6}{*}{$\operatorname{PVDF}(0)$} & \multirow[t]{2}{*}{ NaOCl pH 6} & 60 & 96 & 238 & $6.13 \times 10^{-4}$ & $3.85 \times 10^{-4}$ & $5.60 \times 10^{-4}$ & $-5.23 \times 10^{-5}$ \\
\hline & & 135 & 90 & 259 & $1.31 \times 10^{-3}$ & $4.42 \times 10^{-5}$ & $1.71 \times 10^{-3}$ & $4.06 \times 10^{-4}$ \\
\hline & \multirow[t]{2}{*}{ NaOCl pH 7.5} & 60 & 93 & 246 & $9.49 \times 10^{-4}$ & $2.48 \times 10^{-4}$ & $1.10 \times 10^{-3}$ & $1.51 \times 10^{-4}$ \\
\hline & & 135 & 92 & 234 & $1.07 \times 10^{-3}$ & $1.20 \times 10^{-4}$ & $1.34 \times 10^{-3}$ & $2.75 \times 10^{-4}$ \\
\hline & \multirow[t]{2}{*}{ NaOCl pH 11.5} & 60 & 131 & 312 & $-2.17 \times 10^{-3}$ & $-6.12 \times 10^{-4}$ & $-2.49 \times 10^{-3}$ & $-3.16 \times 10^{-4}$ \\
\hline & & 135 & 133 & 305 & $-2.29 \times 10^{-3}$ & $-5.38 \times 10^{-4}$ & $-2.69 \times 10^{-3}$ & $-4.03 \times 10^{-4}$ \\
\hline \multirow[t]{6}{*}{ PVDF(AH) } & \multirow[t]{2}{*}{ NaOCl pH 6} & 60 & 150 & 503 & $1.97 \times 10^{-3}$ & $8.73 \times 10^{-4}$ & $2.05 \times 10^{-3}$ & $7.51 \times 10^{-5}$ \\
\hline & & 135 & 136 & 431 & $2.66 \times 10^{-3}$ & $1.21 \times 10^{-3}$ & $2.74 \times 10^{-3}$ & $8.25 \times 10^{-5}$ \\
\hline & \multirow[t]{2}{*}{ NaOCl pH 7.5} & 60 & 140 & 454 & $2.45 \times 10^{-3}$ & $1.09 \times 10^{-3}$ & $2.54 \times 10^{-3}$ & $9.08 \times 10^{-5}$ \\
\hline & & 135 & 136 & 430 & $2.66 \times 10^{-3}$ & $1.21 \times 10^{-3}$ & $2.74 \times 10^{-3}$ & $7.89 \times 10^{-5}$ \\
\hline & \multirow[t]{2}{*}{ NaOCl pH 11.5} & 60 & 173 & 611 & $1.09 \times 10^{-3}$ & $5.22 \times 10^{-4}$ & $1.10 \times 10^{-3}$ & $1.39 \times 10^{-5}$ \\
\hline & & 135 & 146 & 518 & $2.15 \times 10^{-3}$ & $8.16 \times 10^{-4}$ & $2.33 \times 10^{-3}$ & $1.74 \times 10^{-4}$ \\
\hline
\end{tabular}

expected to increase faster than the absolute value of $\delta_{\mathrm{S}}$ that is not the case here. The observed behavior can be explained as follows: In solutions of $\mathrm{pH} 11.5$, the reactive species induces selectively the formation of bonds between the shorter PVDF chains. The fraction of low molar mass tends thus to disappear while the fraction of longer chains increases moderately. As a result, the polydispersity index, initially 2.57 , decreases until 2.29 after 135 days. The simplest explanation of such selectivity of the reaction is that it involves chain end groups, for instance double bonds. Indeed chain end groups are concentrated in the low molar mass fraction.

The case of $\operatorname{PVDF}(\mathrm{AH})$ in solutions at $\mathrm{pH} 11.5$ appears simpler since $s$ and $x$ are positive. One can however remark that $s / x \sim 13$, against $33-35$ at $\mathrm{pH} 6.0$ or 7.5. As a result, the DPI value decreases less than in acidified solutions (3.55 after 135 days, against 3.163.17 in $\mathrm{pH} 6.0$ or 7.5 solutions). We cannot exclude that here also a non-random process is superposed to the random one.

To conclude with the SEC results, PVDF macromolecules undergo small but measurable changes indicating that the whole membrane volume has reacted. These changes consist in combined degradation (random chain scission) and crosslinking. Chain scission predominates (slightly on $\operatorname{PVDF}(0)$ and largely on PVDF $(\mathrm{AH})$ ) over crosslinking. As observed from spectrochemical investigations, there is a difference of behavior between solutions at pH 6.0 and 7.5 and solutions at $\mathrm{pH}$ 11.5. In these latter, at least for $\operatorname{PVDF}(0)$, the changes in molar mass distribution indicate a selective attack of short chains, i.e. probably of terminal groups.

\subsection{Crystallinity}

Chain scissions in semi-crystalline polymers having their

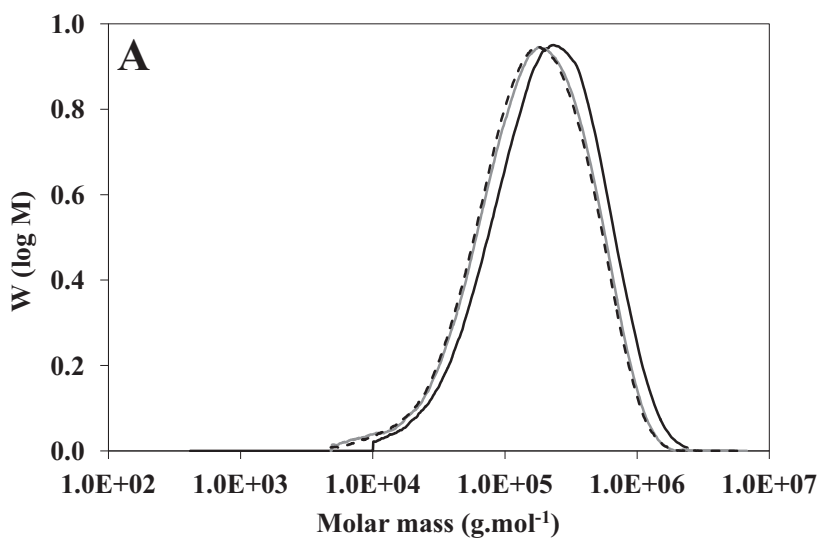

amorphous phase in rubbery state can favor a secondary crystallization named chemi-crystallization [33]. It seemed interesting to study the eventual changes in the degree of crystallinity $\chi_{\mathrm{c}}$ determines from the enthalpy of melting per mass unit $H_{\mathrm{f}}$ :

$\chi_{\mathrm{C}}=\frac{H_{\mathrm{f}}}{H_{\mathrm{f} 0}}$

where $H_{\mathrm{f} 0}=104.6 \mathrm{~J} \mathrm{~g}^{-1}$ is the enthalpy of melting per mass unit of the PVDF crystalline phase[34]. $(\mathrm{AH})$

The results are given in Fig. $6 a$ for PVDF(0) and Fig. $6 b$ for PVDF

These results call for the following comments: In PVDF (AH), the initial melting enthalpy has not been corrected for the presence of additives. If $h_{\mathrm{f}}$ is the measured melting enthalpy for a sample mass $m$, the reported value of $\chi_{\mathrm{c}}$ is an apparent degree of crystallinity and can be written:

$\chi_{c \text { app }}=\frac{h_{\mathrm{f}}}{m H_{\mathrm{f} 0}}=\frac{h_{\mathrm{f}}}{\left(m_{\mathrm{P}}+m_{\mathrm{A}}\right) H_{\mathrm{f} 0}}=\frac{h_{\mathrm{f}}}{m_{\mathrm{P}} H_{\mathrm{f} 0}} \cdot \frac{1}{1+\frac{m_{\mathrm{A}}}{m_{\mathrm{P}}}} \chi_{c}$ PVDF $\frac{m_{\mathrm{P}}}{m_{\mathrm{P}}+m_{\mathrm{A}}}$

where $m_{\mathrm{P}}$ and $m_{\mathrm{A}}$ are the respective polymer and additive masses and $\chi_{\mathrm{c}}$ PVDF is the true degree of crystallinity of PVDF. The results obtained for PVDF(AH) indicate the initial presence of about $13 \%$ additive which is destroyed during exposure while the true degree of crystallinity of PVDF remains unchanged and almost equal to the one of $\operatorname{PVDF}(0)$.

\subsection{Porosity and transport properties}

\subsubsection{Water absorption}

As expected, the unaged membrane $\operatorname{PVDF}(0)$ displays a very

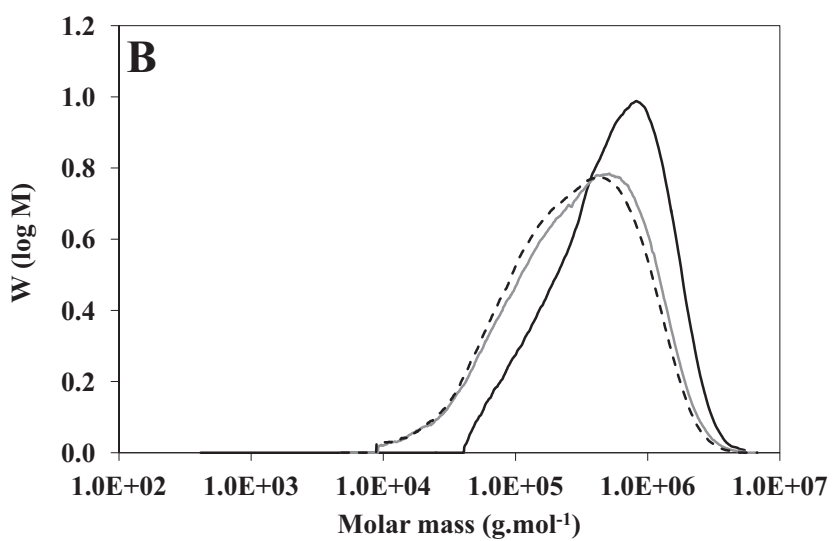

Fig. 5. Chromatograms of $\operatorname{PVDF}(0)(\mathrm{A})$ and $\operatorname{PVDF}(\mathrm{AH})(\mathrm{B})$. Initial (black full line), after ageing 135 days in pH 6.0 (gray full line) and at pH 7.5 (dashed line). 

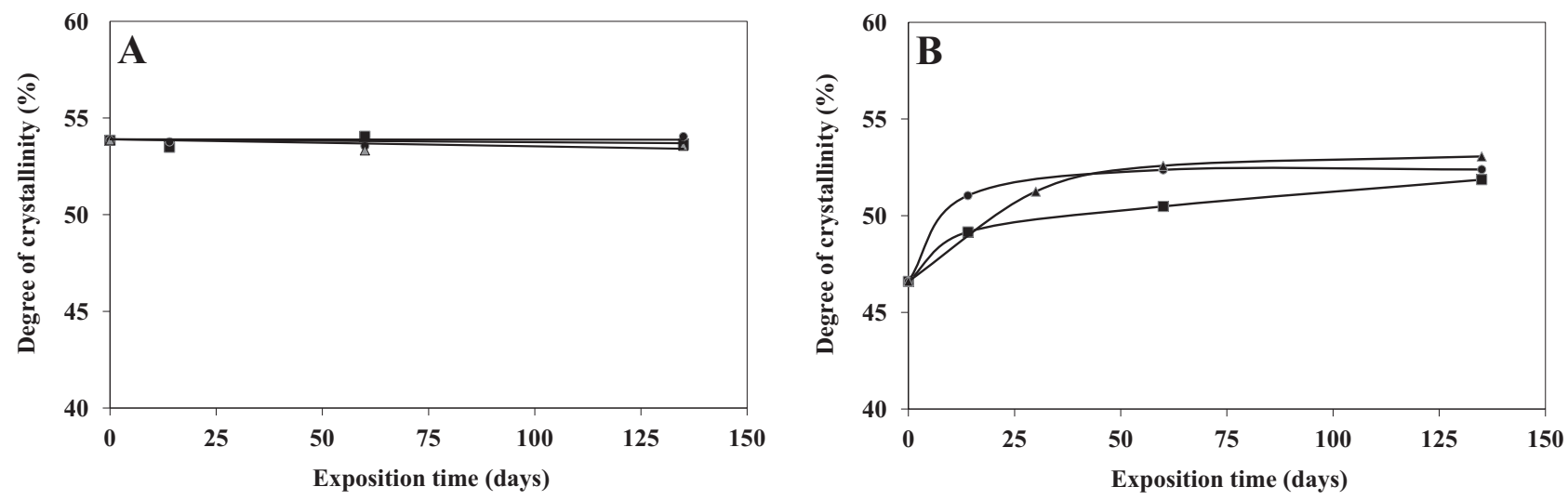

Fig. 6. Degree of crystallinity against exposure time for $\operatorname{PVDF}(0)(A)$ and $\operatorname{PVDF}(A H)(B)$. Squares: $\mathrm{pH}$ 6.0, Circles: pH 7.5, Triangles: pH 11.5.

low water absorption, contrary to the unaged $\operatorname{PVDF}(\mathrm{AH})$, that absorbs up to $\sim 3 \%$ water at $90 \% \mathrm{RH}$. The sorption isotherm displays a positive curvature that can be explained by clustering of the absorbed water or by water adsorption at the pore surface. In both cases, the increase of hydrophilicity would be due to the presence of polar additives such as PEG and PVP. If the additives, insoluble in PVDF, were mainly present at the membrane surface, they would have contributed for a large part to ATR infrared spectra, which is not the case. One can thus conclude that they are almost homogeneously distributed into the PVDF matrix as a solution or a dispersion. The isotherm curvature would be therefore due to clustering.

The sorption isotherms of water in $\operatorname{PVDF}(0)$ before ageing and after 135 days in $\mathrm{NaOCl} 4000 \mathrm{ppm}$ solutions at $40{ }^{\circ} \mathrm{C}$ are shown in Fig. 7.

Ageing has two consequences: first an increase of the water solubility in PVDF, as illustrated by the mass gain values at $90 \% \mathrm{RH}$ (Table 5), second a change of curvature in the region of low activities: the curvature is positive in the unaged sample and tends to become negative in aged samples, that is generally interpreted as the appearance of a Langmuir sorption process. The importance of this process can be represented, in a first approach, by the initial slope of the isotherm (Table 5). These results would suggest that ageing in $\mathrm{NaOCl}$ solutions creates hydrophilic sites, i.e. polar groups in PVDF.

Let us assume, in a first approach, that clustering is negligible and that, at $90 \% \mathrm{RH}$, there is one water molecule per hydrophilic group. The number $n$ of these latter per gram would be given by:

$n=\frac{h}{1800}$

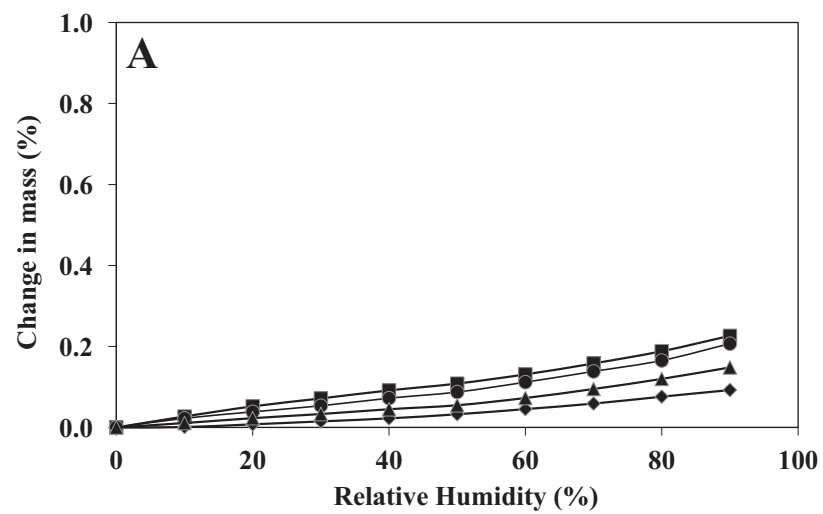

Table 5

Water absorption characteristics of $\operatorname{PVDF}(0)$ before and after 135 days in a $4000 \mathrm{ppm} \mathrm{NaOCl}$ solution at $40^{\circ} \mathrm{C}$

\begin{tabular}{|c|c|c|c|c|}
\hline \multirow[t]{2}{*}{ Exposure conditions } & \multirow[t]{2}{*}{ Initial } & \multicolumn{3}{|c|}{ NaOCl 4000 ppm } \\
\hline & & pH 6.0 & pH 7.5 & pH 11.5 \\
\hline Mass gain at 90\% RH (\%) & 0.09 & 0.23 & 0.22 & 0.15 \\
\hline $\mathrm{n} \times 10^{5}$ & & 13 & 12 & 8 \\
\hline Initial curvature & Positive & Negative & Negative & Zero \\
\hline Initial slope of the isotherm & 1.2 & 26 & 22 & 11 \\
\hline$\left(\frac{d m}{d a} \times 100\right)$ & & & & \\
\hline
\end{tabular}

where $h$ is the mass gain at 90\% RH. The values of $n$ are listed in Table 5. It can be seen that the number of created hydrophilic sites (for instance $8 \times 10^{-5}$ at $\mathrm{pH} 6.0$ ) is considerably lower than the number of chain scissions (for instance $171 \times 10^{-5}$ at $\mathrm{pH} 6.0$ ). In the case where clustering would exist, the number of hydrophilic sites would be again lower.

The sorption isotherms of $\operatorname{PVDF}(\mathrm{AH})$ exposed 135 days in $\mathrm{NaOCl}$ 4000 ppm solutions at $40{ }^{\circ} \mathrm{C}$ are shown in Fig. 8 .

In the unaged sample, the high value of water absorption at $90 \% \mathrm{RH}\left(2.9 \%=1.61 \mathrm{~mol} \mathrm{~kg}^{-1}\right)$ is clearly due to the presence of hydrophilic additives $\left(0.26 \mathrm{~mol} \mathrm{~kg} \mathrm{~kg}^{-1}\right.$ of PVP monomer units and about $1.5 \mathrm{~mol} \mathrm{~kg}^{-1}$ of PEG monomer units). The strong positive curvature of the isotherm indicates clustering (Zimm \& Lundberg). As expected from spectrochemical data, ageing, which destroys the additives, induces a marked decrease of water absorption (Table 6) and, as for $\operatorname{PVDF}(0)$, the appearance of a negative curvature linked to Langmuir absorption process (Table 6).

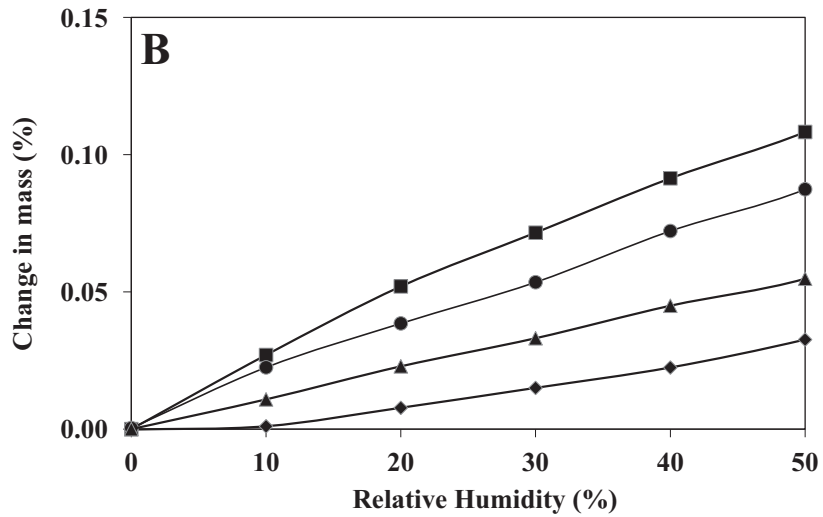

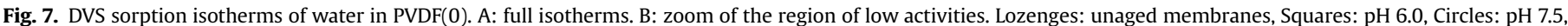
Triangles: $\mathrm{pH} 11.5$. 

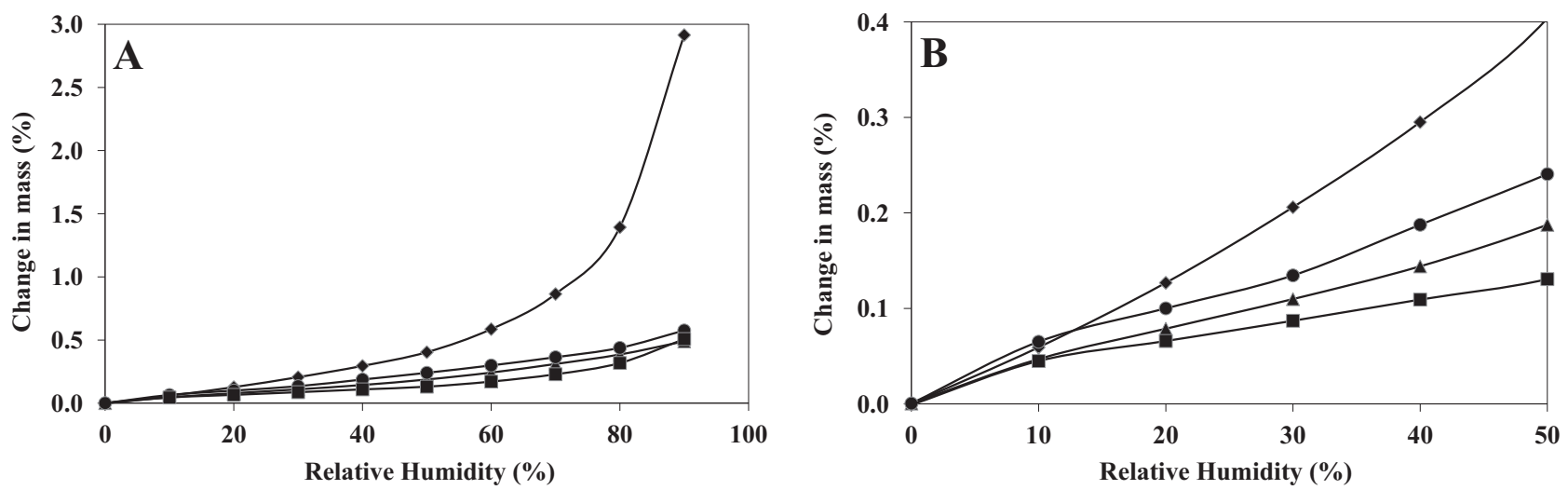

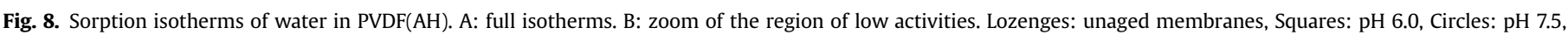
Triangles: $\mathrm{pH} 11.5$.

Table 6

Water absorption characteristics of $\operatorname{PVDF}(\mathrm{AH})$ before and after 135 days ageing in a $\mathrm{NaOCl} 4000 \mathrm{ppm}$ solution at $40^{\circ} \mathrm{C}$.

\begin{tabular}{lllll}
\hline Exposure conditions & Initial & \multicolumn{2}{l}{ NaOCl $\mathbf{4 0 0 0} \mathbf{~ p p m}$} & \\
\cline { 3 - 5 } \cline { 3 - 5 } & & pH 6.0 & pH 7.5 & pH 11.5 \\
\hline Mass gain at 90\% RH (\%) & 2.9 & 0.51 & 0.58 & 0.49 \\
$\boldsymbol{n} \times \mathbf{1 0}^{\mathbf{5}}$ & 160 & 28 & 32 & 27 \\
Initial curvature & Positive & Negative & Negative & Negative \\
Initial slope of the isotherm & 59 & 46 & 65 & 47 \\
$\left(\frac{d m}{d a} \times 100\right)$ & & & & \\
\hline
\end{tabular}

Despite the (presumably complete) destruction of the additives, the water equilibrium concentration at $90 \% \mathrm{RH}$ remains significantly higher in $\operatorname{PVDF}(\mathrm{AH})$ than in $\operatorname{PVDF}(0)$. It seems thus that some polar groups coming from additives are grafted to PVDF chains but unfortunately, their concentration, lower than $10^{-3} \mathrm{~mol} \mathrm{~g}^{-1}$, is below the sensitivity threshold of common analytical tools.

The appearance of a negative curvature is noteworthy. Since it appears in both types of membranes, it can be attributed to a property of PVDF degraded chains. A Langmuir process is linked to the existence of sites establishing especially strong (but reversible) interactions with water molecules. Unfortunately the nature of these sites is unknown in the case under study.

\subsubsection{Permeability to liquid water}

Permeability measurements leaded to the results resumed by Fig. 9.

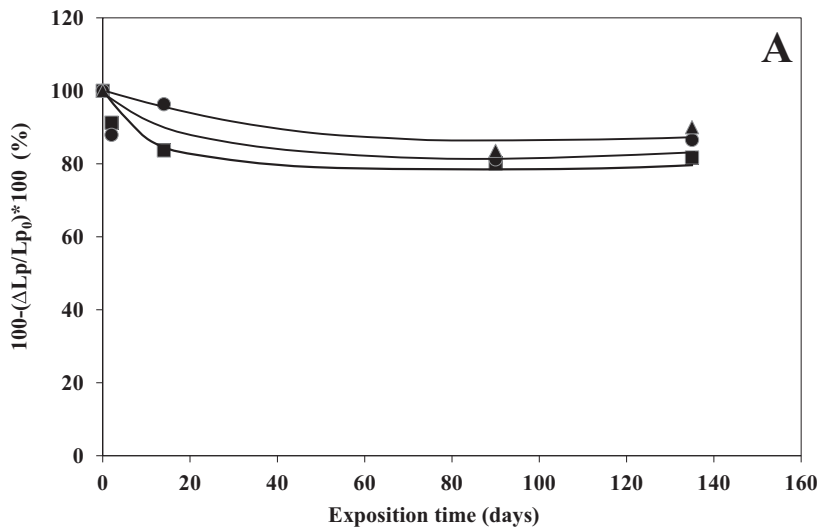

For both membranes a slight decrease can be observed but the variation of permeability remains of the order of experimental errors.

\subsubsection{Porosity}

The results of nitrogen absorption measurements are summarized in Table 7. It appears that, in the case of $\operatorname{PVDF}(0)$, ageing has no effect on porosity. In the case of $\operatorname{PVDF}(\mathrm{AH})$, noticeable differences can be observed between the initial state and aged ones: the specific area is multiplied by about 3 , the mesoporous volume is multiplied by about 2 and the average pore size is considerably decreased. The analysis of the mesopore size distribution seems to show that during ageing, mesopores of size lower than $10 \mathrm{~nm}$ have appeared at the expense of mesopores of $10-20 \mathrm{~nm}$. All these changes can be attributed, no doubt, to the destruction of the polymeric additives but information is lacking to have a clear understanding of the process.

\subsubsection{Membrane selectivity}

$\operatorname{PVDF}(0)$ is a microfiltration membrane devoted to bacteria retention. The measurements made with Escherichia coli after 135 days ageing in a $4000 \mathrm{ppm} \mathrm{NaOCl}$ solution at $40{ }^{\circ} \mathrm{C}$ are summarized in Table 8 . No significant change was observed, the membrane keeps its good retention properties after ageing.

$\operatorname{PVDF}(\mathrm{AH})$ is designed for virus filtration. The measurements made with MS2 after 135 days ageing in $\mathrm{NaOCl} 4000 \mathrm{ppm}$ at $40{ }^{\circ} \mathrm{C}$ are shown in Table 8.

It appears that ageing improves the membrane selectivity, which can be explained by the fact that the average pore size and the membrane hydrophilicity are reduced, both modifications being expected to have an influence on virus retention.

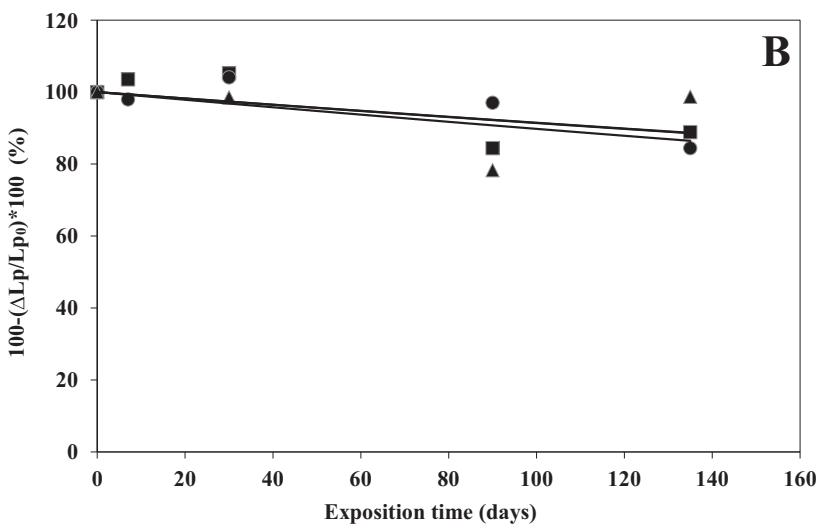

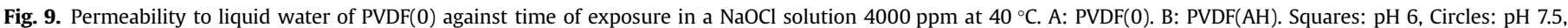
Triangles: pH 11.5 . 
Table 7

Porosity characteristics from nitrogen absorption measurements.

\begin{tabular}{|c|c|c|c|c|}
\hline Sample & Ageing conditions & $\begin{array}{l}\text { Specific area } \\
\left(\mathrm{m}^{2} \mathrm{~g}^{-1}\right)\end{array}$ & $\begin{array}{l}\text { Mesoporous } \\
\text { volume } \\
\left(\mathrm{cm}^{3} \text { liquid } \mathrm{g}^{-1}\right)\end{array}$ & $\begin{array}{l}\text { Pore size } \\
(\mu \mathrm{m})\end{array}$ \\
\hline \multirow[t]{4}{*}{ PVDF(0) } & Initial & $10.0 \pm 2.3$ & 0.03 & $0.02-0.07$ \\
\hline & $\begin{array}{l}\text { NaOCl pH 6-135 } \\
\text { days }\end{array}$ & $11.3 \pm 1.9$ & 0.03 & $0.02-0.07$ \\
\hline & $\begin{array}{l}\mathrm{NaOCl} \text { pH } 7.5-135 \\
\text { days }\end{array}$ & $10.8 \pm 1.1$ & 0.03 & $0.02-0.07$ \\
\hline & $\begin{array}{l}\text { NaOCl pH 11.5- } \\
135 \text { days }\end{array}$ & $10.2 \pm 3.7$ & 0.03 & $0.02-0.07$ \\
\hline \multirow[t]{4}{*}{ PVDF(AH) } & Initial & $18.4 \pm 2.8$ & 0.07 & $0.01-0.07$ \\
\hline & $\begin{array}{l}\text { NaOCl pH 6-135 } \\
\text { days }\end{array}$ & $51.4 \pm 1.6$ & 0.15 & 0.004 \\
\hline & $\begin{array}{l}\mathrm{NaOCl} \text { pH 7.5-135 } \\
\text { days }\end{array}$ & $63.8 \pm 1.4$ & 0.16 & 0.004 \\
\hline & $\begin{array}{l}\text { NaOCl pH 11.5- } \\
135 \text { days }\end{array}$ & $50.4 \pm 4.3$ & 0.18 & 0.004 \\
\hline
\end{tabular}

Table 8

Bacteria retention by the PVDF(0) and PVDF(AH) membranes.

\begin{tabular}{lll}
\hline Ageing conditions & Retention of bacteria $(E$. coli) & LRV \\
\hline Initial & $100 \%$ & 7.6 \\
NaOCl pH 7.5 - 135 days & $100 \%$ & 7.5 \\
NaOCl pH 11.5 - 135 days & $100 \%$ & 7.6 \\
\hline Ageing conditions & Retention of virus (MS2) & LRV \\
\hline Initial & $93.8 \pm 0.4 \%$ & $1.19 \pm 0.05$ \\
NaOCl pH 7.5 - 135 days & $99.9 \pm 0.0 \%$ & $4.25 \pm 0.14$ \\
NaOCl pH 11.5 - 135 days & $99.9 \pm 0.0 \%$ & $3.78 \pm 0.07$ \\
\hline
\end{tabular}

To summarize the results obtained on porosity, transport and filtration performance measurements, ageing for 135 days in $\mathrm{NaOCl} 4000 \mathrm{ppm}$ solutions at $40{ }^{\circ} \mathrm{C}$ has a negligible effect on the additive free membrane PVDF(0). This is consistent with the results of physico-chemical analysis showing that the polymer has undergone only minute transformations. The case of PVDF(AH) is different because the relatively fast transformation of the additives induces a significant decrease in the average pore size as well as physico-chemical modifications of the membrane surface (especially a decrease of the membrane hydrophilicity), improving slightly but significantly the membrane selectivity.

\subsection{Longitudinal shrinkage}

The fiber length has been measured before and during ageing.

A

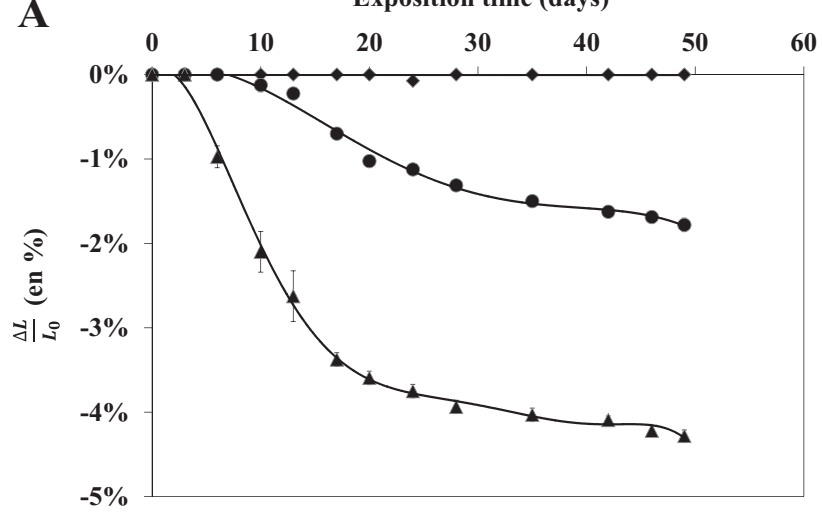

The results are shown in Fig. 10. The fibers undergo a considerable shrinkage in bleach, but not in pure water.

\section{Discussion}

\subsection{Primary events}

It can be reasonably assumed that, at least for $\mathrm{pH}=6.0$ or 7.5 , the reactive species are radicals coming from the solution. The exact nature of these radicals remains unknown but the only way they have to attack the regular PVDF chain is to abstract hydrogens on methylenes $\left(\mathrm{CH}_{2}\right)$. According to NMR data, these radicals are almost unreactive with head to tail monomer units, probably because $\mathrm{CF}_{2}$ groups exert a repulsive effect on electronegative species. In head to head sequences however, the shielding effect of fluorine is interrupted and methylenes become accessible to radicals. The "primary" chemical event would be in this case the hydrogen abstraction on ethylene groups:

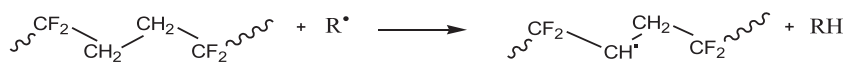

The resulting macroradical will be named $\mathrm{P}^{\bullet}$. It can react in principle by three ways: disproportionation, coupling or rearrangement (mainly by $\beta$ scission). Let us consider these reactions;

\subsection{Double bond formation}

The first possible route of double bond formation is dehydrofluorination. According to the authors $[20,21]$ it could take place on head to tail sequences. The DHF mechanism is ionic, favored in strongly basic media. Thus here, the solution at $\mathrm{pH} 11.5$ would be expected the most reactive that is contradicted by experimental results. Other possible routes for double bond formation are disproportionation between secondary macroradicals or chain scission.

The disproportionation process can be ascribed:

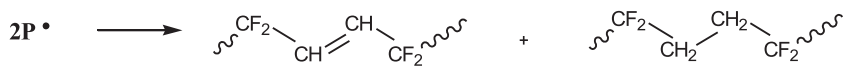

Let us recall that the amorphous phase of PVDF is in its rubbery state at the ageing temperature; it is thus stirred by ample cooperative motions and behaves as a viscous liquid in which such encounters between macroradicals are possible. Furthermore, disproportionations involving one macroradical $\mathrm{P}^{\bullet}$ and one

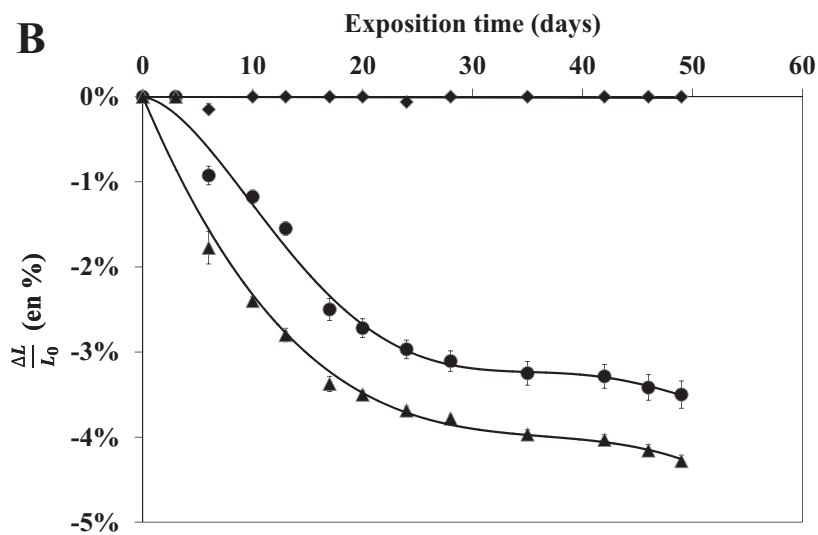

Fig. 10. Longitudinal shrinkage of $\operatorname{PVDF}(0)(\mathrm{A})$ and $\operatorname{PVDF}(\mathrm{AH})(\mathrm{B})$ during exposure at $40{ }^{\circ} \mathrm{C}$, in pure water (lozenges), at pH 7.5 (circles) and at $\mathrm{pH} 11.5$ (triangles). 
microradical, for instance $\mathrm{HO}^{\bullet}$, are not excluded; in all the cases they would lead to vinylene units.

The chain scission process (in a head to head sequence) can be ascribed:

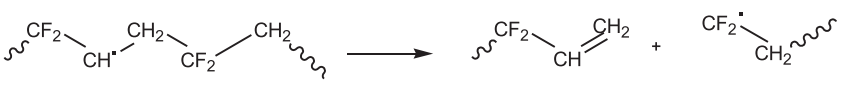

If this process was predominant, one would observe a correlation between the formation of double bonds and the decrease of molar mass.

\subsection{Crosslink formation}

Crosslinking results mainly from coupling of two macroradicals:

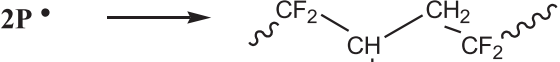

$$
\begin{aligned}
& \left.\sim \mathrm{NF}_{2}\right|_{\mathrm{CH}}>\mathrm{CH}_{2} \longrightarrow \mathrm{CF}_{2} \sim{ }^{\sim}
\end{aligned}
$$

The existence of a crosslinking process confirms the existence of bimolecular encounters between macroradicals, but SEC data indicate that there is less than one crosslink per ten initial number average chains. The yield of crosslinking is considerably lower than the yield of competitive processes such as disproportionation.

\subsection{Chain scission}

Generally chain scissions result from oxidation. This latter leads to alkoxy radicals and these latter rearrange by chain scission with aldehyde or ketone formation [35]. Oxidation products were not observed here but at the concentration of created chain ends they would be perhaps undetectable. Anyhow primary radicals can also eventually undergo $\beta$ scissions. The corresponding mechanism has been presented above.

The following scenario can be thus imagined: in "pure" PVDF, coupling and $\beta$ scission have almost equal probabilities so that the yield of chain scission is just slightly higher than the yield of crosslinking. In PVDF(AH), the additives favor slightly chain scission and double bond formation but do not affect crosslinking. The following hypothesis can be made: Additive molecules are considerably more reactive than PVDF. Their reaction with the reactive species coming from the bath gives radicals. A part of these radicals react with PVDF and induces disproportionation, coupling and $\beta$ scission of which the global rate is increased in proportion with the radical concentration. Coupling can occur as well with PVDF macroradicals as with additive ones. There is thus some grafting of additive molecules on PVDF trunk. But these grafts are very unstable; they are destroyed by the bleach solution. This scenario can explain two above results: first the yield of crosslinking remains low, despite the increase in global reaction rate, because a part of coupling processes, involving additive molecules, do not lead, finally, to crosslinking. Second, the total degradation of a graft cannot restore exactly the PVDF chain; an extraneous group must remain linked to the carbon which has undergone the initial radical attack. This extraneous group can explain the residual hydrophilicity excess observed in $\operatorname{PVDF}(\mathrm{AH})$, compared to $\operatorname{PVDF}(0)$.

\subsection{Non-random reaction at $\mathrm{pH} 11.5$}

As mentioned above, the changes of molar mass distribution observed for $\operatorname{PVDF}(0)$ aged in $\mathrm{NaOCl}$ solutions at $\mathrm{pH} 11.5$ can be explained by a selective reaction of the shortest chains which are transformed into long chains by coupling or addition reactions. The simpler hypothesis would involve the addition of macroradicals on terminal double bonds, for instance:

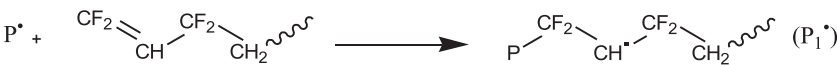

$$
\begin{aligned}
& \mathrm{P}_{1}+\mathrm{R}^{\cdot} \longrightarrow \mathrm{P}^{-\mathrm{CF}_{2}} \mathrm{CHR}^{\prime}{ }^{\mathrm{CF}_{2}} \mathrm{CH}_{2}{ }^{N^{N}}
\end{aligned}
$$

In this scheme, $\mathrm{P}^{\bullet}$ would be a macroradical, $\mathrm{R}^{\bullet}$ could be indifferently a macro or a microradical. The problem here is to identify the nature of the reactive species coming from the bath; as a matter of fact, radical precursors are in principle absent of basic (natural) $\mathrm{NaOCl}$ solutions. Can we envisage ionic mechanisms? The question remains open.

\subsection{Shrinkage}

Shrinkage displays many interesting characteristics: (i) it needs the presence of a chemical reaction since it does not occur in pure water; (ii) but it is relatively fast since it is almost complete after 20-30 days; it is faster at $\mathrm{pH} 11.5$ than at $\mathrm{pH} 7.5$, in other words it is not correlated with the global reaction rate as determined by IR, NMR or SEC; (iii) its amplitude is almost the same for both membranes that is surprising. As a matter of fact, in $\operatorname{PVDF}(\mathrm{AH})$, according to the rule of volume additivity, the quasi complete additive loss is expected to lead to a volumic shrinkage of the order of $10 \%$, i.e. a longitudinal shrinkage of about 3\% assuming a quasi-isotropic shrinkage. This component of the shrinkage is inexistent in $\operatorname{PVDF}(0)$, this latter is thus expected to shrink less than $\operatorname{PVDF}(\mathrm{AH})$, which is not the case. Apparently the extent of shrinkage is almost independent of the additive presence, at least at $\mathrm{pH}$ 11.5. All the above observations lead to the following (partial) explanations:

The hollow fibers display some longitudinal chain orientation resulting from their thermo-mechanical history during processing. This orientation cannot relax spontaneously at $40{ }^{\circ} \mathrm{C}$ in water. The system behaves as a polymer which has been crosslinked in the stretched state. Orientation relaxes rapidly in the presence of bleach as if the so-called "crosslinks" were highly reactive in this medium. The difference between $\mathrm{pH} 7.5$ and $\mathrm{pH} 11.5$ could be tentatively explained as follows: only a fraction of the "crosslinks" which are broken at $\mathrm{pH} 11.5$ are reactive at $\mathrm{pH}$ 7.5. This fraction is smaller in $\operatorname{PVDF}(0)$ than in $\operatorname{PVDF}(\mathrm{AH})$.

\subsection{Porosity, selectivity}

By which mechanism polymer degradation can modify the membrane porosity? The unique way, to our knowledge, is embrittlement and fracture of pore walls. Here, the chain scission process is expected to induce PVDF embrittlement [18]. To check its effects, we have performed tensile tests on the fibers. The results are summarized by Table 9 .

The interpretation of these data in terms of structure changes is very difficult owing to the complex fiber morphology, i.e. the wide variety of strain states in pore walls. However, what is sure is that, after 135 days ageing, the fibers have kept most of their initial ductility, which would be difficult to reconcile with the hypothesis of polymer embrittlement in a significant fraction of pore walls. It has been shown that, for the family of linear semi-crystalline polymers to which PVDF belongs, one can define a so-called critical molar mass $M_{\mathrm{c}}^{\prime}$ such as, for $M_{\mathrm{w}}>M_{\mathrm{c}}^{\prime}$ the polymer is ductile and for $M_{\mathrm{w}}<M_{\mathrm{c}}^{\prime}$ it is brittle [18]. $M_{\mathrm{c}}^{\prime}$ is of the order of $70 \mathrm{~kg} \mathrm{~mol}^{-1}$ for polyethylene and polyoxymethylene and $200 \mathrm{~kg} \mathrm{~mol}^{-1}$ for polypropylene. $M_{c}^{\prime}$ value is unknown for PVDF but it is not unreasonable to suppose that it is lower than $234 \mathrm{~kg} \mathrm{~mol}^{-1}$, the lowest $M_{w}$ value found in this study. These considerations lead to assume that, for the exposure conditions and durations under study, the structure modifications of the PVDF macromolecules 
Table 9

Longitudinal tensile properties (at $23^{\circ} \mathrm{C}, 0.016 \mathrm{~s}^{-1}$ strain rate) of the fibers before and after 135 days ageing at $40{ }^{\circ} \mathrm{C}$.

\begin{tabular}{|c|c|c|c|c|c|c|}
\hline \multirow[t]{2}{*}{ Sample } & \multirow[t]{2}{*}{ Ageing conditions } & \multirow{2}{*}{$\begin{array}{l}\text { Apparent Young's modulus } \\
\text { (E in } \mathrm{MPa})\end{array}$} & \multicolumn{2}{|c|}{ Yield coordinates } & \multicolumn{2}{|c|}{ Rupture coordinates } \\
\hline & & & $\begin{array}{l}\text { Strain } \\
\left(\varepsilon_{\mathrm{p}} \text { in \%) }\right.\end{array}$ & $\begin{array}{l}\text { Engineering Stress } \\
\left(\sigma_{\mathrm{p}} \text { in Mpa }\right)\end{array}$ & $\begin{array}{l}\text { Strain } \\
\left(\varepsilon_{\mathrm{r}} \text { in \%) }\right.\end{array}$ & $\begin{array}{l}\text { Engineering Stress } \\
\left(\sigma_{\mathrm{r}} \text { in Mpa }\right)\end{array}$ \\
\hline \multirow[t]{4}{*}{ PVDF(0) } & Initial & $72 \pm 4$ & $32 \pm 1$ & $7.7 \pm 0.1$ & $96 \pm 7$ & $8.9 \pm 0.1$ \\
\hline & $\mathrm{NaOCl}$ pH 6 & $73 \pm 4$ & $32 \pm 1$ & $7.5 \pm 0.1$ & $73 \pm 4$ & $8.6 \pm 0.1$ \\
\hline & NaOCl pH 7.5 & $65 \pm 10$ & $34 \pm 1$ & $7.5 \pm 0.1$ & $65 \pm 10$ & $8.3 \pm 0.2$ \\
\hline & NaOCl pH 11.5 & $68 \pm 5$ & $34 \pm 2$ & $7.6 \pm 0.1$ & $81 \pm 9$ & $8.7 \pm 0.1$ \\
\hline \multirow[t]{4}{*}{ PVDF(AH) } & Initial & $55 \pm 3$ & $26 \pm 2$ & $3.1 \pm 0.1$ & $103 \pm 7$ & $4.2 \pm 0.1$ \\
\hline & NaOCl pH 6 & $76 \pm 8$ & $17 \pm 1$ & $3.1 \pm 0.1$ & $77 \pm 8$ & $3.8 \pm 0.1$ \\
\hline & NaOCl pH 7.5 & $75 \pm 4$ & $15 \pm 1$ & $3.1 \pm 0.1$ & $80 \pm 9$ & $3.8 \pm 0.1$ \\
\hline & NaOCl pH 11.5 & $69 \pm 3$ & $18 \pm 2$ & $3.0 \pm 0.1$ & $77 \pm 5$ & $3.7 \pm 0.1$ \\
\hline
\end{tabular}

constituting the "matrix" of the membrane, cannot directly affect the porosity and the selectivity of the membrane.

Certain of these modifications can however have an indirect effect through the shrinkage. As a matter, it is difficult to imagine a, longitudinal shrinkage without a modification of certain transverse dimensions and, eventually, pore size. Unfortunately, the (chemical) shrinkage mechanism is not understood and will need a supplementary research.

In the case of PVDF(AH), three major changes are observed: the polymer degradation by random chain scission, the decrease of average pore size and the decrease of hydrophilicity linked to the destruction of polar groups belonging to the additive. Changes of pore size presumably involve structure modifications at a dimension scale not directly linked to molar mass as long as the polymer retains its toughness. Furthermore, additive (partial) destruction cannot be the direct cause of pore size decrease. We are thus forced to imagine an indirect effect of these phenomena through a mechanism which remains to establish.

\section{Conclusions}

Two PVDF based membranes have been studied and compared: one, additive free, dedicated to micro-filtration, the other, modified by hydrophilic additives (polyvinylpyrrolidone and polyethylene glycol), dedicated to ultra-filtration. They have been exposed at $40^{\circ} \mathrm{C}$ in $\mathrm{NaOCl} 4000 \mathrm{ppm}$ solutions of various $\mathrm{pH}$ values for maximum durations of 135 days and various material and functional properties have been measured.

The results of physico-chemical investigations confirm the well-known chemical stability of PVDF; however, this stability is not total since it was shown that PVDF macromolecules undergo chain scission and crosslinking at low rate. Chain scission always predominates (slightly for $\operatorname{PVDF}(0)$, strongly for $\operatorname{PVDF}(\mathrm{AH})$ ) over crosslinking but, after 135 days in the chosen conditions, the global molar mass changes remain too low to induce polymer embrittlement and change in porosity. It is clearly shown that the PVDF degradation rate is higher in acidified solutions ( $\mathrm{pH} 6.0$ and 7.5) than in non-modified one ( $\mathrm{pH} 11.5)$. However the fiber undergoes longitudinal shrinkage of about $4-5 \%$ induced by reaction of the membrane with the hypochlorite solution; the non-modified solution is more active than acidified ones in this process of which the mechanism remains unknown.

Contrary to PVDF, the polymeric additives of PVDF(AH) are highly reactive with $\mathrm{NaOCl}$ solutions; they are completely destroyed, leading to a decrease of the membrane hydrophilicity, but their destruction improves the membrane selectivity by a decrease of the average porosity.

Finally, as far as functional properties are concerned, the studied membranes can be considered stable for durations of 4.5 months, in the chosen conditions whatever the $\mathrm{pH}$ value in the 6.0-11.5 interval. The existence of a slow PVDF degradation process indicates however that the polymer will reach in a finite time its (unknown but probably higher than $50 \mathrm{~kg} \mathrm{~mol}^{-1}$ ) critical molar mass beyond which the pore walls will become brittle and the membrane will lose its selectivity.

\section{References}

[1] P. Bernardo, E. Drioli, G. Golemme, Ind. Eng. Chem. Res, 48 (2009) 4638.

[2] M.M. Pendergast, E.M. Hoek, Energy Environ. Sci. 4 (2011) 1946.

[3] E.M. Hoek, A. Jawor, in: J. Contescu, C.K. Putyera (Eds.) Encyclopedia of Nanoscience and Nanotechnology, Schwarz, 2002, p. 2399.

[4] G.-D. Kang, Y.-M. Cao, J. Membr. Sci. 463 (2014) 145

[5] F. Liu, N.A. Hashim, Y. Liu, M.M. Abed, K. Li, J. Membr. Sci. 375 (2011) 1.

[6] P. Wang, Z. Wang, Z. Wu, Q. Zhou, D. Yang, Chem. Eng. J. 162 (2010) 1050.

[7] M. Khayet, C. Feng, K. Khulbe, T. Matsuura, Polymer 43 (2002) 3879.

[8] C. Güell, R.H. Davis, J. Membr. Sci. 119 (1996) 269.

[9] M. Hashino, K. Hirami, T. Ishigami, Y. Ohmukai, T. Maruyama, N. Kubota, H. Matsuyama, J. Membr. Sci. 384 (2011) 157.

[10] A. Al-Amoudi, R.W. Lovitt, J. Membr. Sci. 303 (2007) 4.

[11] N. Porcelli, S. Judd, Sep. Purif. Technol. 71 (2010) 137.

[12] E. Gaudichet-Maurin, F. Thominette, J. Membr. Sci. 282 (2006) 198.

[13] S. Rouaix, C. Causserand, P. Aimar, J. Membr. Sci. 277 (2006) 137.

[14] E. Arkhangelsky, D. Kuzmenko, V. Gitis, J. Membr. Sci. 305 (2007) 176.

[15] V. Gitis, R.C. Haught, R.M. Clark, J. Gun, O. Lev, J. Membr. Sci. 276 (2006) 185

[16] I.M. Wienk, E.E.B. Meuleman, Z. Borneman, T. van den Boomgaard, C. A. Smolders, J. Polym. Sci. Part A: Polym. Chem. 33 (1995) 49.

[17] J.-J. Qin, F.-S. Wong, Y. Li, Y.-T. Liu, J. Membr. Sci. 211 (2003) 139.

[18] J.-J. Qin, Y. Li, L.-S. Lee, H. Lee, J. Membr. Sci. 218 (2003) 173.

[19] B. Pellegrin, R. Prulho, A. Rivaton, S. Thérias, J.-L. Gardette, E. GaudichetMaurin, C. Causserand, J. Membr. Sci. 447 (2013) 287.

[20] D. Brewis, I. Mathieson, I. Sutherland, R. Cayless, R. Dahm, Int. J. Adhes. Adhes. 16 (1996) 87.

[21] G. Ross, J. Watts, M. Hill, P. Morrissey, Polymer 41 (2000) 1685.

[22] W. Benzinger, B. Parekh, J. Eichelberger, Sep. Sci. Technol. 15 (1980) 1193.

[23] F. Vigo, C. Uliana, B. Cavazza, F. Salvemini, J. Membr. Sci. 21 (1984) 295.

[24] N. Awanis Hashim, Y. Liu, K. Li, Chem. Eng. Sci. 66 (2011) 1565.

[25] S. Hajibabania, A. Antony, G. Leslie, P. Le-Clech, Sep. Purif. Technol. 90 (2012) 204.

[26] V. Puspitasari, A. Granville, P. Le-Clech, V. Chen, Sep. Purif. Technol. 72 (2010) 301.

[27] E. Arkhangelsky, D. Kuzmenko, N.V. Gitis, M. Vinogradov, S. Kuiry, V. Gitis, Tribol. Lett. 28 (2007) 109

[28] M. Rabuni, N.N. Sulaiman, M. Aroua, C.Y. Chee, N.A. Hashim, Chem. Eng. Sci. 122 (2015) 426.

[29] I. Levitsky, A. Duek, E. Arkhangelsky, D. Pinchev, T. Kadoshian, H. Shetrit, R. Naim, V. Gitis, J. Membr. Sci. 377 (2011) 206.

[30] R. Gregorio Jr, M. Cestari, J. Polym. Sci. Part B: Polym. Phys. 32 (1994) 859.

[31] K. Yadav, K. Morison, M.P. Staiger, Polym. Degrad. Stab. 94 (2009) 1955.

[32] O. Saito, J. Phys. Soc. Jpn. 13 (1958) 198.

[33] B. Fayolle, X. Colin, L. Audouin, J. Verdu, Polym. Degrad. Stab. 92 (2007) 231.

[34] M. Neidhöfer, F. Beaume, L. Ibos, A. Bernès, C. Lacabanne, Polymer 45 (2004) 1679.

[35] J. Verdu, Oxydative Ageing of Polymers, John Wiley \& Sons, United States, 2012. 